\title{
GROWTH OF CITRUS ROOTSTOCKS UNDER ALUMINIUM STRESS IN HYDROPONICS
}

\author{
Walter Esfrain Pereira ${ }^{1 *}$; Dalmo Lopes de Siqueira ${ }^{2,5}$; Mario Puiatti2; Carlos Alberto Martínez; \\ Luiz Carlos Chamhum Salomão2; Paulo Roberto Cecon ${ }^{4}$ \\ ${ }^{1}$ UFPB/CCA - Depto. de Ciências Fundamentais e Sociais - Campus Universitário - CEP: 58397 - 000 - Areia, PB. \\ ${ }^{2}$ Depto. de Fitotecnia - UFV - CEP: 36571-000 - Viçosa, MG. \\ ${ }^{3}$ Depto. de Biologia - USP/FFCLRP - Av. Bandeirantes, 3900 - CEP: 14040-901 - Ribeirão Preto,SP. \\ ${ }^{4}$ Depto. de Informática - UFV. \\ ${ }^{5} \mathrm{CNPq}$ Fellow. \\ ${ }^{*}$ Corresponding author <wep@cca.ufpb.br>
}

ABSTRACT: Plants present different degrees of adaptation to aluminium (Al) concentrations in the soil, and the understanding of this characteristic can lead to a viable option for the utilization of acid soils. The objective of this experiment was to evaluate the effects of five Al concentrations $\left(0,50,100,200\right.$, and $\left.400 \mu \mathrm{mol} \mathrm{L}^{-1}\right)$ on the growth of 'Rangpur' lime ( Citrus limonia Osbeck) and 'Volkamer' lemon (Citrus volkameriana Hort. ex Tan.), and tangerine rootstocks 'Cleópatra' ( Citrus reshni Hort. ex Tan) and 'Sunki' ( Citrus sunkiHort. ex Tan.), in hydroponic culture. The treatments were arranged in a randomized block design, with four replications. For all rootstocks, the relative growth rate in terms of plant total fresh matter increased under low and, decreased under large Al concentrations. Growth of the shoot, leaf area ratio and leaf weight ratio decreased for all rootstocks in the presence of Al. The 'Rangpur' lime had a decrease of the root system growth, starting from $23 \mu \mathrm{mol} \mathrm{L}^{-1}$ of Al. For the remaining rootstocks, this growth reached maximum values at 91 to $117 \mu \mathrm{mol} \mathrm{L}^{-1}$ of $\mathrm{Al}$, respectively. Considering all the evaluated characteristics of plant growth, the ' Rangpur' lime was the most susceptible to Al.

Key words: Citrus sp., relative growth rate, principal components, nutrient solution

\section{CRESCIMENTO DE PORTA-ENXERTOS DE CITROS SUBMETIDOS A ESTRESSE POR ALUMÍNIO, EM CULTIVO HIDROPÔNICO}

\begin{abstract}
RESUMO: As plantas apresentam diferentes graus de tolerância aos efeitos tóxicos do alumínio (AI), e a exploração dessa característica pode ser uma opção viável para a utilização dos solos ácidos. Este experimento teve como objetivo avaliar os efeitos de cinco concentrações de alumínio $\left(0,50,100,200\right.$ e $400 \mu \mathrm{mol} \mathrm{L}^{-1} \mathrm{de}$ Al) sobre o crescimento dos porta-enxertos limoeiros 'Cravo' ( Citrus limonia Osbeck) e 'Volkameriano' ( Citrus volkameriana Hort. ex Tan.), e tangerineiras 'Cleópatra' (Citrus reshni Hort. ex Tan) e 'Sunki' (Citrus sunki Hort. ex Tan.) em cultivo hidropônico. Os tratamentos foram distribuídos no delineamento de blocos casualizados, com quatro repetições e duas plantas por parcela. Em todos os porta-enxertos, a taxa relativa de crescimento da matéria fresca total da planta aumentou na presença de baixas concentrações de Al e decresceu na presença de maiores concentrações. O crescimento da parte aérea, a relação de área foliar e a relação de massa foliar diminuíram em todos os porta-enxertos na presença do Al. No limoeiro 'Cravo' verificou-se decréscimo de crescimento do sistema radicular a partir de $23 \mu \mathrm{molL}^{-1}$ de Al. Nos demais portaenxertos, esse crescimento atingiu valores máximos na presença de 91 a $117 \mu \mathrm{mol} \mathrm{L}^{-1}$ de $\mathrm{Al}$, respctivamente. Considerando-se todas as características avaliadas do crescimento de planta, o limoeiro 'Cravo' foi o portaenxerto mais sensível ao Al.

Palavras-chave: Citrus, taxa relativa de crescimento, componentes principais, solução nutritiva
\end{abstract}

\section{INTRODUCTION}

As citriculture expands worldwide, with a harvested area increasing from 6.2 million ha, in 1993, to 7.4 million ha in 2000 (FAO, 2000), and particularly in Brazil, where the harvested orange area evolved from 800 thousand ha, in 1993, to 1 million ha in 1999 (FNP Consultoria e Comércio, 2000), new cropping areas are under exploration. In these areas, the soil can present unfavorable conditions for the citrus crop, however, one of the major problems is aluminium (Al) toxicity, a limiting factor in many acid soils, which have an estimated extension between $40 \%$ and $70 \%$ of the soils available for agriculture (Rengel, 1992).
In the State of São Paulo, Brazil, approximately $70 \%$ of the soils where citriculture is practiced present restrictions to root growth due to soil Al. In other regions of Brazil, it is common to observe orchards established in soils originally covered by savanna (cerrado) vegetation, which have low fertility, high acidity and high Al concentration (Demattê \& Vitti, 1992).

Anderson (1987) verified an increase in the productivity of 'Valência' orange trees grown on acid soil $(\mathrm{pH} \approx 5)$, increasing from 46 to $61 \mathrm{~kg}$ per tree and per year for plants grown on limed soil $(\mathrm{pH} \approx 7)$. In the State of Paraná, Brazil, Fidalski et al. (1999) verified a negative correlation between the fruit productivity of 'Pêra' orange 
trees and the Al concentration in the soil, as well as with the total soil acidity.

Toxicity by Al cannot always be corrected economically by means of conventional liming practices (Foy, 1988). In several countries, one of the main reasons for this is that many areas that present soil acidity problems are distant from the agricultural lime production sites (Myers \& Depauw, quoted by Ginting et al., 1998). Another difficulty is to correct acid strata that occur at greater depths in the soil, an acidity that in addition to that of the surface stratum, is increased due to the utilization of some nitrogen fertilizers, such as ammonium sulfate (Mason, 1980).

The variability in the adaptation to $\mathrm{Al}$ can be observed between plants of the same genus or between varieties of the same species (Nunes et al., 1995, Simon et al., 1994, Massot et al., 1999), and the use of genetic material that is tolerant or resistant to toxicity by Al becomes an important option for the occupation of acid soils.

With regard to rootstocks utilized in citriculture, Lin \& Myhre (1991) concluded, based on the production of plant total fresh matter, that the citrus rootstocks evaluated by them could be classified, as to their tolerance to $\mathrm{Al}$, in the following way: 'Cleopatra' tangerine > 'Rough' lemon $>$ Citrus aurantium > 'Swingle' Citrumelo > 'Carrizo' citrange. Magalhães (1987) evaluated the tolerance of citrus rootstocks to $\mathrm{Al}$ added to the soil, verifying that $\mathrm{Al}$ significantly influenced the growth of the root system and of the aerial part, with the 'Rugoso da Florida' lemon as the most tolerant to Al, followed by the 'Cleopatra' tangerine and by the 'Rangpur' lime.

The generalized use of 'Rangpur' lime with the most diverse scions, soil types and climates does not adequately address the needs of all varieties, preventing the plant from expressing its complete productivity potential (Pompeu Jr., 1991). Therefore, the need for diversifying the rootstocks utilized in Brazilian citriculture becomes evident, decreasing the risk of an eventual outbreak of diseases or pests, and allowing the economic exploration of areas that present the most diverse edaphoclimatic conditions.

Toxicity by $\mathrm{Al}$ is morphologically characterized by the thickening and paralyzation of root growth, due to cell wall hardening and cell division inhibition (Foy, 1978), and physiologically due to alterations in nutrient absorption and utilization, especially of $\mathrm{P}$ (Channel \& Mielniczuk, 1983). Roots that have been damaged by aluminium are characteristically short, thick and brittle, with the absence of fine ramifications, and are very little efficient in absorbing water and nutrients (Foy, 1974). In addition to the root system, Al affects the growth of the shoot. The mechanisms that have been proposed to explain alterations caused by Al include: a) decreased cell division and elongation in the roots, resulting in limited exploration of the soil for nutrient and water absorption and translocation, b) interaction of $\mathrm{Al}^{3+}$ with essential elements $(\mathrm{Ca}, \mathrm{Mg}, \mathrm{P})$, resulting in decreased absorption and translocation of these elements, leading to deficiency symptoms, and, c) translocation of toxic amounts of $\mathrm{Al}$ to the aerial part of the plant (Foy, 1988).

There is much research carried out in relation to annual crops with the objective of evaluating the effects of aluminium on plant growth. However, for fruit tree species in general, and particularly for citrus, there are few published reports on the subject. Since growth-related characteristics constitute the criterion utilized to identify the degree of tolerance to aluminium for a species or variety, it is important to evaluate the effect of aluminium on citrus rootstock growth, extending the commercial exploration of soils to those that show high concentration of that element in the strata explored by the root system.

The objective of this research was to evaluate the effects of aluminium on the growth of the root systems and aerial parts of four citrus rootstocks.

\section{MATERIAL AND METHODS}

This research was carried out in a greenhouse located in Viçosa, MG, Brazil, during the period February to April, 1998.

Mature fruits were harvested from rootstock plants, seeds washed, selected, demucilaged, rinsed in running water, and left to dry in the shade for a week. After drying, a dry treatment was performed with the fungicide captan at a rate of $500 \mathrm{mg}$ of active ingredient per each $100 \mathrm{~g}$ of seeds. Next, the seeds were stored for a month in a cold storage chamber at $5^{\circ} \mathrm{C}$, and then sown in plastic boxes containing vermiculite as substrate for germination. They were irrigated, whenever necessary, with Hoagland solution containing $1 / 4$ of its original concentration of salts. The seedlings, with a mean height of $7.7 \mathrm{~cm}$, were selected according to size and transferred to $12 \mathrm{~L}$-capacity Styrofoam boxes, containing Hoagland nutrient solution modified according to Simon et al. (1994), consisting of the following salts: $500 \mu \mathrm{mol} \mathrm{L} \mathrm{L}^{-1} \mathrm{KNO}_{3} ; 500 \mu \mathrm{mol} \mathrm{L^{-1 }}$ $\mathrm{Ca}\left(\mathrm{NO}_{3}\right)_{2} \cdot 4 \mathrm{H}_{2} \mathrm{O} ; 200 \mu \mathrm{mol} \mathrm{L}{ }^{-1} \mathrm{MgSO}_{4} \cdot 7 \mathrm{H}_{2} \mathrm{O} ; 100 \mu \mathrm{mol} \mathrm{L}$ $\mathrm{KH}_{2} \mathrm{PO}_{4} ; 50 \mu \mathrm{mol} \mathrm{L}{ }^{-1} \mathrm{KCl} ; 46 \mu \mathrm{mol} \mathrm{L}^{-1} \mathrm{H}_{3} \mathrm{BO}_{3} ; 20 \mu \mathrm{mol} \mathrm{L} \mathrm{L}^{-1}$ Fe-EDTA; $2 \mu \mathrm{mol} \mathrm{L}{ }^{-1} \mathrm{MnCl}_{2} \cdot 4 \mathrm{H}_{2} 0 ; 1 \mu \mathrm{mol} \mathrm{L}^{-1} \mathrm{ZnSO}_{4} \cdot 7 \mathrm{H}_{2} \mathrm{O}$; $0.3 \mu \mathrm{mol} \mathrm{L}{ }^{-1} \mathrm{CuSO}_{4} \cdot 5 \mathrm{H}_{2} \mathrm{O}$ and $0.5 \mu \mathrm{mol} \mathrm{L}^{-1} \mathrm{NaMoO}_{4} \cdot 2 \mathrm{H}_{2} 0$. Seven days later, the Al was added to the solution in the form of $\mathrm{Al}_{2}\left(\mathrm{SO}_{4}\right)_{3} \cdot 18 \mathrm{H}_{2} \mathrm{O}$.

The solution was aerated by means of and air compressor. The $\mathrm{pH}$ in the solution was monitored daily and maintained at 4.0 by adding $0.1 \mathrm{~mol} \mathrm{~L}^{-1} \mathrm{HCl}$ or $\mathrm{NaOH}$ solutions, as necessary. Initially, the solutions were changed every two weeks; later on, during the last month, they were changed weekly. Each box received two seedlings of each rootstock, totaling eight seedlings.

The plants were grown for 70 days under natural photoperiod and room temperature conditions $\left(21^{\circ} \mathrm{C}\right.$ minimum, $35^{\circ} \mathrm{C}$ maximum and $28^{\circ} \mathrm{C}$ mean).

The factors under study were five concentrations of $\mathrm{Al}$ in the nutrient solution (0,50,100, 200, and 400 $\mu \mathrm{mol} \mathrm{L}{ }^{-1}$ ) and four citrus rootstocks: 'Rangpur' lime (Citrus 
limonia Osbeck) and 'Volkamer' lemon (Citrus volkameriana Hort. ex Tan.), and 'Cleopatra' (Citrus reshni Hort. ex Tan) and 'Sunki' (Citrus sunki Hort. ex Tan.) tangerines.

The experiment was carried out in a split-plot scheme, where plots corresponded to Al concentrations and sub-plots were rootstocks. The treatments were distributed in a randomized block design, with four replicates. Each experimental unit consisted of two plants.

The fresh matter mass of the entire plant was determined at the beginning and at the end of the experiment, and based on these values the relative growth rate (RGR) was estimated, according to Hunt (1990): $R G R=\left(\ln Y_{2}-\ln Y_{1}\right) /\left(t_{2}-t_{1}\right)$ where, $R G R=$ relative growth rate; $Y_{1}=$ fresh matter mass at time $t_{1} ; Y_{2}$ $=$ fresh matter mass at time $t_{2}$

The leaf area was determined with a portable area-measuring device (DELTA-T, model MK2, Delta-T Devices Ltd., England). Later on, samples were placed in a forced-ventilation oven at $70^{\circ} \mathrm{C}$ to constant weight, and the dry matter masses for root and shoot were determined. The root/shoot ratio was estimated based on dry matter mass. The leaf area ratio (LAR) was estimated by dividing the leaf area by the total dry matter mass of seedlings. The leaf weight ratio (LWR) was estimated by dividing the leaf dry matter mass by the total dry matter mass of seedlings.

The length and total area of the root system were determined by digitizing roots on a flatbed scanner. The image resolution was $300 \mathrm{dpi}$, in black and white. Then, the images were processed with the Sigma Scan Pro 5.0 Demo software (SPSS).

Analysis of variance was used to study the effects of Al concentrations on the characteristics under evaluation, making also use of regression analysis at $10 \%$ by $\mathrm{F}$ test. The rootstocks were compared among themselves by orthogonal contrasts (Table 1 ) of percentage values relative to the absence of $\mathrm{Al}$, which was considered as a $100 \%$ value. The analyses were performed by means of the SAS MIXED procedure (Littel et al., 1996; SAS Institute, 1999).

Due to the high correlation that existed between the variables which were determined, and with the objective of facilitating the classification of the rootstocks with respect to aluminium tolerance, the percentage values, relative to the absence of aluminium, were

Table 1 - Coefficients of orthogonal contrasts utilized to compare rootstocks of 'Rangpur' lime (CR) and 'Volkamer' lemon (VL) and of 'Sunki' (SK) and 'Cleopatra' (CL) tangerins.

\begin{tabular}{lcccc}
\hline \multirow{2}{*}{ Contrasts } & \multicolumn{5}{c}{ Rootstocks } \\
\cline { 2 - 5 } & $\mathrm{CR}$ & $\mathrm{SK}$ & $\mathrm{VL}$ & $\mathrm{CL}$ \\
\hline CR vs VL & 1 & 0 & -1 & 0 \\
SK vs CL & 0 & 1 & 0 & -1 \\
LIM. vs TAN. & 1 & -1 & 1 & -1 \\
\hline
\end{tabular}

LIM = lemon and lime trees; TAN = tangerine trees. submitted to principal components analyses (Cruz \& Regazzi, 1994; Johnson \& Wichern, 1998; SAS Institute, 1999). The rootstock clustering was based on the Tocher method, applied to the principal component scores.

\section{RESULTS AND DISCUSSION}

In all rootstocks, the relative growth rate (RGR) initially increased in the presence of aluminium in the nutrient solution, reaching maximum values between 15 and $35 \mu \mathrm{mol} \mathrm{L}{ }^{-1}$ of Al for the 'Rangpur' lime (CR) and the 'Cleopatra' (CL) tangerine, respectively. The RGR was smaller in the presence of higher concentrations. This initial increase, in percentage values, was higher for the tangerines. For the original values, the lemons presented higher RGR values in the absence of aluminium in the nutrient solution (Figure 1). In percentage values, the RGR for the 'Sunki' (SK) tangerine was more affected as compared to the CL tangerine (Tables 2 and 3 ). No difference was detected between the two lemons, the growth of which was more affected by aluminium as compared to the two tangerines.

The results obtained in this research are in agreement with those reported in other researches carried out with different species, in which aluminium caused a decrease in the relative growth rate (Oleksyn et al., 1996; Neogy et al., 1999). According to Lin \& Myhre (1991), the total fresh matter of several citrus rootstocks submitted to low aluminium concentrations $\left(<100 \mu \mathrm{mol} \mathrm{L}{ }^{-1}\right)$ increased relative to the control, decreasing with the increase in Al concentration.

The possible mechanisms that caused the initial increase in RGR, at low Al concentrations, could be the same as for the net photosynthesis rate, i.e.: a) in acid solutions containing low Al concentrations, competition of $\mathrm{Al}^{3+}$ with $\mathrm{H}^{+}$occurs for absorption sites on the cell surface (Kinraide \& Parker, 1987), and b) $\mathrm{Al}^{3+}$ stimulates $\mathrm{H}^{+}$extrusion, which is essential for root growth in acid $\mathrm{pH}$ (Yan et al., 1992), since, with the exception of the 'Volkamer' lemon (VL) tree, initial increases in net photosynthesis rate (Pereira et al., 2000) and RGR were verified, and these are indicative that the increase in RGR was due to the increase in the net photosynthesis rate.

For all rootstocks under evaluation the dry matter mass of the root system (DMMRS) increased in the presence of low aluminium concentrations, and the maximum values were obtained with the estimated doses of $36(\mathrm{CR})$ to $117(\mathrm{VL}) \mu \mathrm{mol} \mathrm{L} \mathrm{L}^{-1} \mathrm{Al}$. The smallest percentage increases were verified for the 'Rangpur' lime. In the absence of $\mathrm{Al}$, the highest absolute values were verified for the two lemons (Figure 1). For relative values, considering the mean for the five Al concentrations, the greatest inhibition of root dry matter accumulation was observed for the 'Rangpur' lime. When compared with the two tangerines, the lemons experienced greater inhibition, but this difference was due to the CR lemon (Tables 2 and 3). 
Nogueira et al. (1989) did not verify any Al effect on dry matter production of the 'Volkamer' lemon tree root system at aluminium concentrations from 0 to $2,222 \mu \mathrm{mol}$ $\mathrm{L}^{-1}$. However, at the concentration of $555 \mu \mathrm{mol} \mathrm{L}^{-1}$, they verified an increase, relative to the control, of $51 \%$ and $8 \%$ on 'Sunki' and 'Rangpur' lime, respectively, while a decrease occurred at the highest concentrations. Similarly to the results obtained in this experiment, the authors also verified a higher sensitivity of 'Rangpur' lime to Al.

Pinto (1999) verified that the dry matter in the root system of 'Volkamer' lemon seedlings grown at a concentration of $370 \mu \mathrm{mol} \mathrm{L}^{-1} \mathrm{Al}$ presented increases up to $169 \%$, as compared to seedlings grown in the absence of $\mathrm{Al}$ in nutrient solution. Therefore, the dry matter of the root system is such a characteristic that, in most situations, would not be the most suitable to evaluate the degree of aluminium tolerance.

The total length and area of the root system (TLRS and TARS) increased up to a certain Al concentration, reaching their maximum at an estimated value from $23(\mathrm{CR})$ to 103 (VL) $\mu \mathrm{mol} \mathrm{L}^{-1} \mathrm{Al}$ (Figure 2). In relative values, the 'Rangpur' lime was the most affected by aluminium in relation to total length and area in the root system. With respect to total length, the 'Sunki' tangerine was more inhibited as compared to 'Cleopatra' (Tables 2 and 3). Clune \& Copeland (1999) observed maximum growth of canola roots in the presence of $40 \mu \mathrm{mol} \mathrm{L}^{-1} \mathrm{Al}$ in the nutrient solution, due to an increase in size and number of cells; at higher concentrations, root growth inhibition occurred. In addition, according to Santos et al. (1999), the root system length in 'Rangpur' lime seedlings exposed to $277 \mu \mathrm{mol} \mathrm{L}^{-1}$ Al, for 84 days, decreased $21 \%$ relative to the control. In 'Swingle' citrumelo, however, it decreased $49 \%$.

With the exception of the 'Rangpur' lime, the values for the three evaluated characteristics (DMMRS, TLRS and TARS), up to a concentration of $400 \mu \mathrm{mol} \mathrm{L}^{-1}$ $\mathrm{Al}$, were higher than those obtained in the absence of aluminium in the nutrient solution (Figures 1 and 2), which would apparently indicate beneficial effects of the aluminium on the root system functionality, responsible for water and nutrient absorption. However, this absorption occurs especially through absorbing root-hairs present in the lateral roots (Kowloski \& Pallardi, 1997), the amount of which, in this experiment, increased only up to $50 \mu \mathrm{mol} \mathrm{L}^{-1}$ aluminium. For higher concentrations, root segments were thicker, a gradual decrease was verified in the amount of lateral roots, and consequently, of absorbing root-hairs.

Table 2 - Mean values of growth characteristics, relative to the control (=100\%), of five aluminum rates, for 'Rangpur' lime (CR) and 'Volkamer' lemon (VL) and for 'Sunki' (SK) and 'Cleopatra' (CL) tangerines.

\begin{tabular}{|c|c|c|c|c|}
\hline \multirow{2}{*}{ Caracteristic } & \multicolumn{4}{|c|}{ Rootstocks } \\
\hline & $\mathrm{CL}$ & $\mathrm{CR}$ & SK & $\mathrm{VL}$ \\
\hline Relativ arowith rate of total frech plant matter & 715 & 90 & 853 & 1086 \\
\hline $\begin{array}{l}\text { Relativ growth rate of total tresn piant matter } \\
\text { Root dry mass }\end{array}$ & 88.8 & 146.5 & $\begin{array}{r}05.5 \\
154.9\end{array}$ & 156.0 \\
\hline Root total area & 89.9 & 152.9 & 140.1 & 171.9 \\
\hline Root total length & 90.0 & 146.6 & 133.7 & 192.6 \\
\hline Foliar area & 54.1 & 74.3 & 72.9 & 66.6 \\
\hline Leaf dry matter & 51.1 & 71.5 & 65.7 & 63.5 \\
\hline Root/shoot ratio & 213.9 & 223.7 & 234.0 & 273.5 \\
\hline Leaf area ratio & 77.1 & 80.4 & 74.2 & 70.7 \\
\hline Leaf weight ratio & 71.9 & 76.7 & 66.3 & 66.2 \\
\hline
\end{tabular}

Table 3 - Estimate of contrast values relative to the control (=100\%), of five aluminum rates, for growth-related characteristics of 'Rangpur' lime (CR) and 'Volkamer' lemon (VL) and of 'Sunki' (SK) and 'Cleopatra' (CL) tangerines.

\begin{tabular}{|c|c|c|c|}
\hline \multirow{2}{*}{ Caracteristic } & \multicolumn{3}{|c|}{ Contrasts } \\
\hline & CR vs VL & SK vs CL & LIM. vs TAN. \\
\hline Relativ growth rate of total fresh plant matter & -13.8 & $-17.8^{*}$ & $-21.3^{* *}$ \\
\hline Root dry mass & $-66.1^{* *}$ & -9.5 & $-29.4^{* *}$ \\
\hline Root total area & $-50.2^{* *}$ & -19.1 & $-47.4^{* *}$ \\
\hline Root total length & $-43.7^{* *}$ & $-46.0^{* *}$ & $-57.8^{* *}$ \\
\hline Foliar area & $-18.8^{* *}$ & 7.8 & -7.0 \\
\hline Leaf dry matter & $-14.6^{*}$ & 8.0 & $-9.1^{*}$ \\
\hline Root/shoot ratio & -20.2 & $-49.8^{* *}$ & $-24.7^{* *}$ \\
\hline Leaf area ratio & 2.9 & $9.8^{* *}$ & 0.1 \\
\hline Leaf weight ratio & $5.6^{*}$ & $10.5^{\star *}$ & -2.4 \\
\hline
\end{tabular}

Lim. $=$ Lemon and lime; Tan. $=$ Tangerine. ${ }^{*},{ }^{* *}$ : significant at 5 and $1 \%$, respectively, by $\mathrm{F}$ test. 
The leaf area and the dry matter mass of leaves (DMML) decreased in the presence of aluminium in the nutrient solution for all evaluated rootstocks (Figure 3 ). In relative values, the greatest decrease was observed for the 'Rangpur' lime (Tables
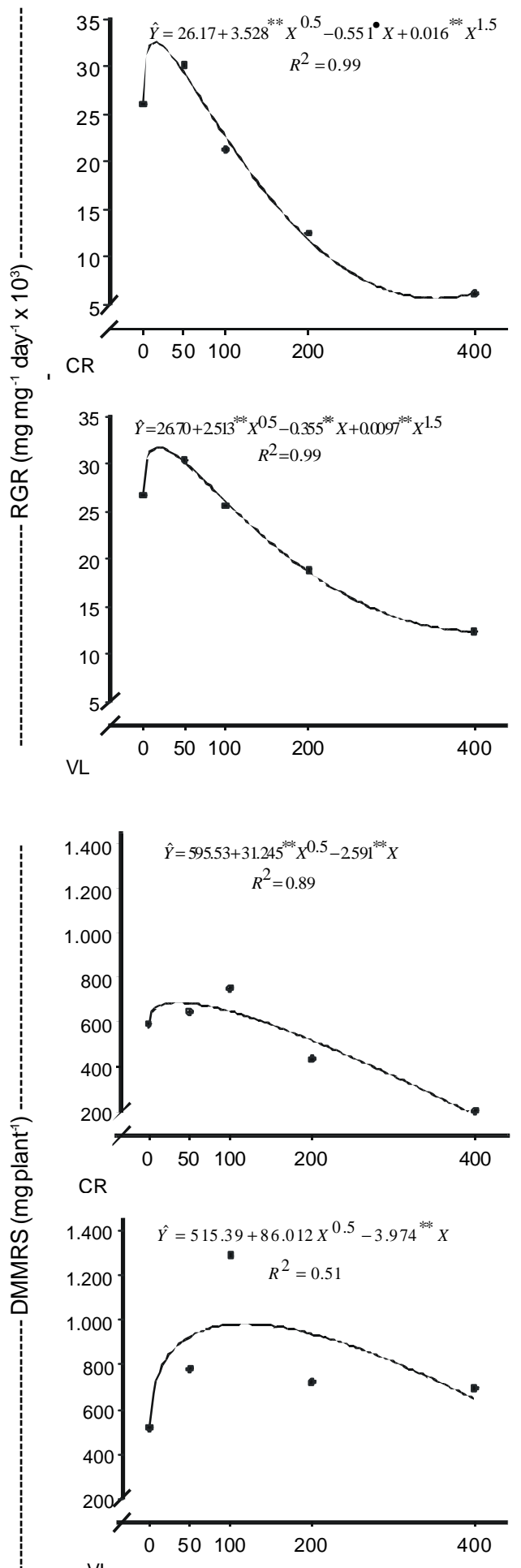

2 and 3), and no differences were detected between the tangerines. Because of the greater decrease in DMML verified for Rangpur' lime, the mean relative value of the lemons was significantly lower as compared to the tangerines.
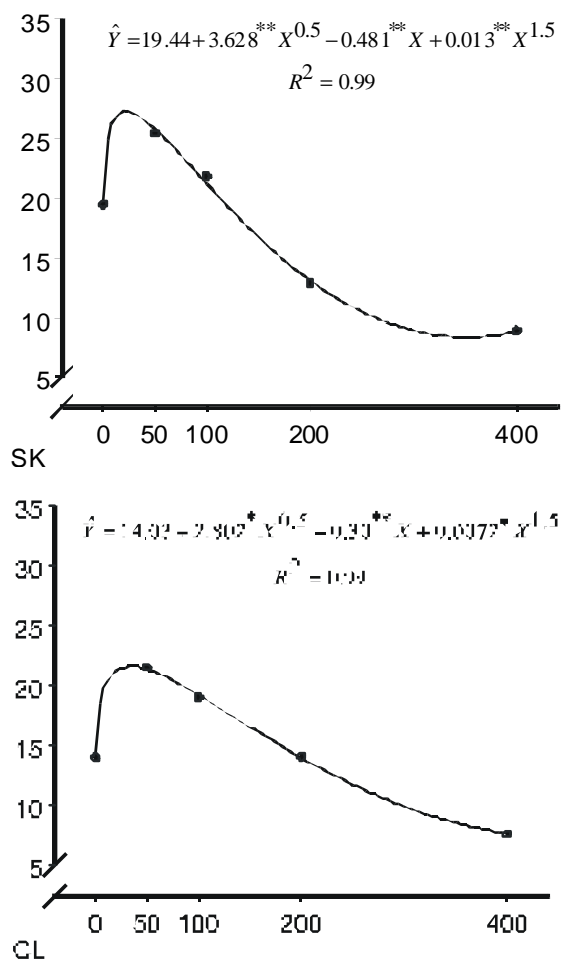

Al $\left(\mu \mathrm{mol} \mathrm{L}{ }^{-1}\right)$
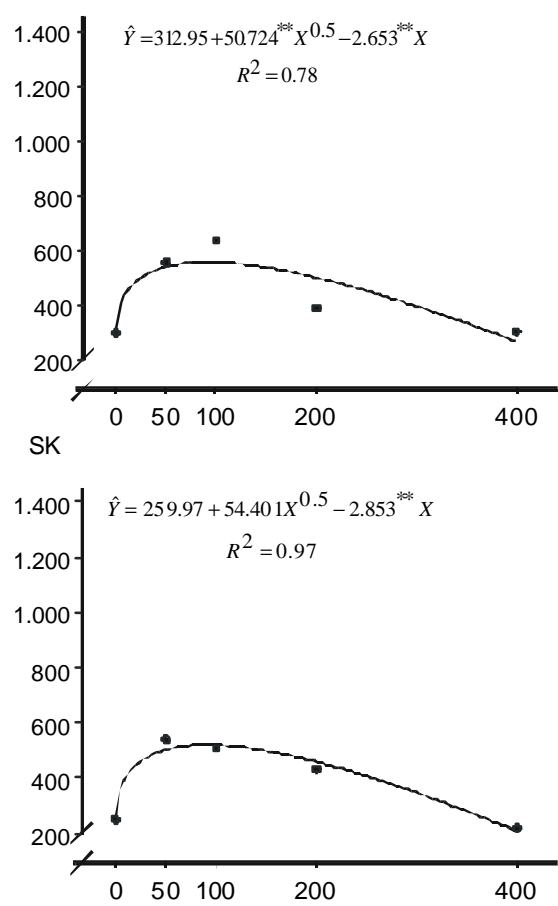

Al $\left(\mu \mathrm{mol} \mathrm{L}{ }^{-1}\right)$

$\cdot,{ }^{*},{ }^{* *}=$ Significant at 10,5 and $1 \%$, respectively, by $\mathrm{F}$ test.

Figure 1 - Relative growth rate of plant total fresh matter (RGR) and dry matter of the root system (DMMRS) for 'Rangpur' lime (CR) and 'Volkamer' lemons (VL) and for 'Sunki' (SK) and 'Cleopatra' (CL) tangerines, as a function of the aluminum (Al) concentration in the nutrient solution. 
According to Nogueira et al. (1989), the leaf dry matter mass for 'Volkamer' lemon and 'Rangpur' limes and 'Sunki' tangerine decreased linearly with the increase of $\mathrm{Al}$ concentration in the nutrient solution, and for the highest concentration there were decreases of $63 \%, 58 \%$ and $41 \%$, respectively, in relation to the control. Vasconcellos et al. (1989) verified linear decreases in leaf dry matter of 'Rangpur' lime and 'Cleopatra' tangerine seedlings, submitted to aluminium levels in the soil utilized as substrate. According to Santos et al. (1999), the leaf area and the dry matter mass of leaves of 'Rangpur' lime, decreased from $19 \%$ to $23 \%$ in the presence of aluminium. In addition to reducing the photosynthesis rate (Pereira et al., 2000), aluminium
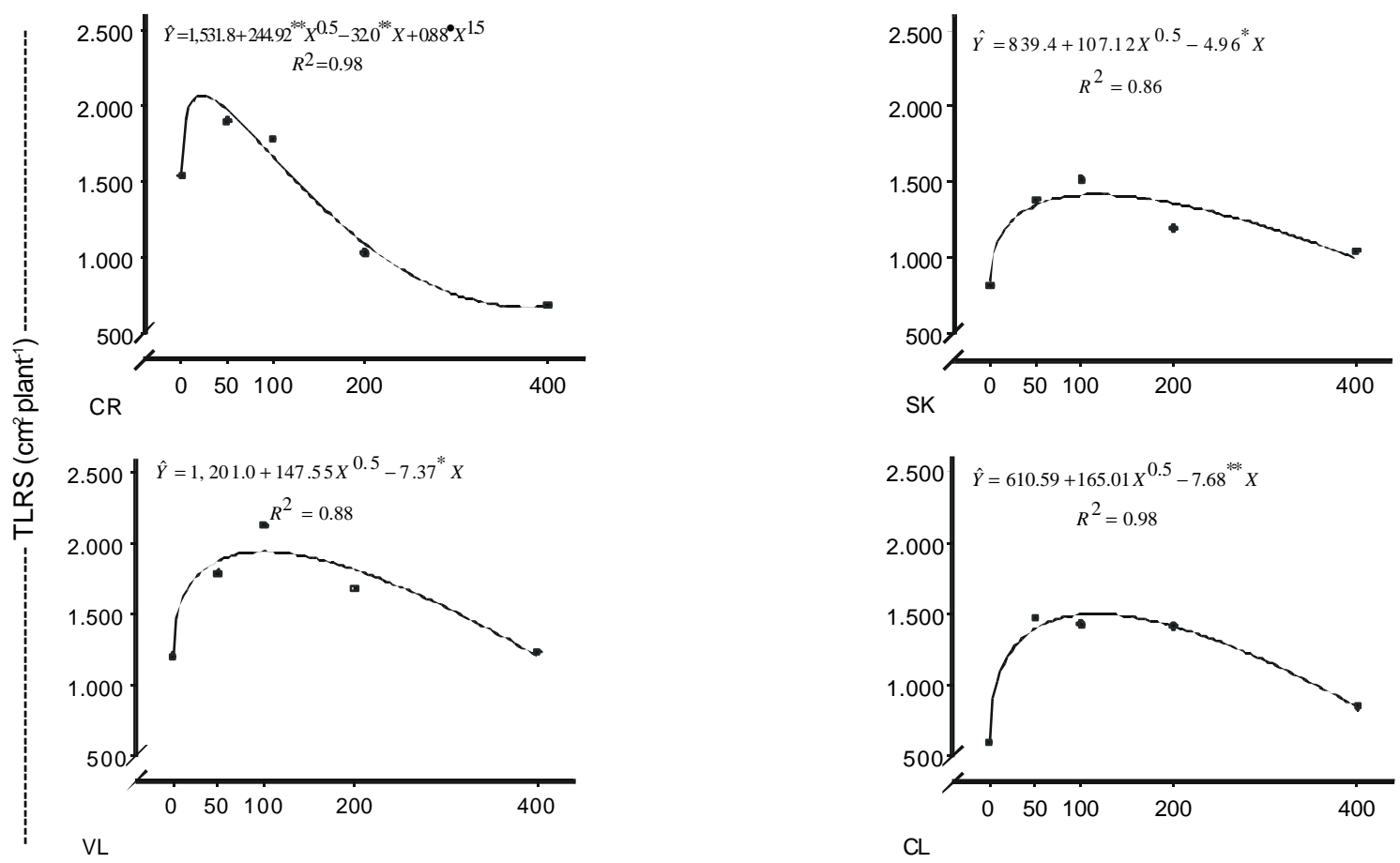

$\mathrm{CL}$

$\mathrm{Al}\left(\mu \mathrm{mol} \mathrm{L}{ }^{-1}\right)$
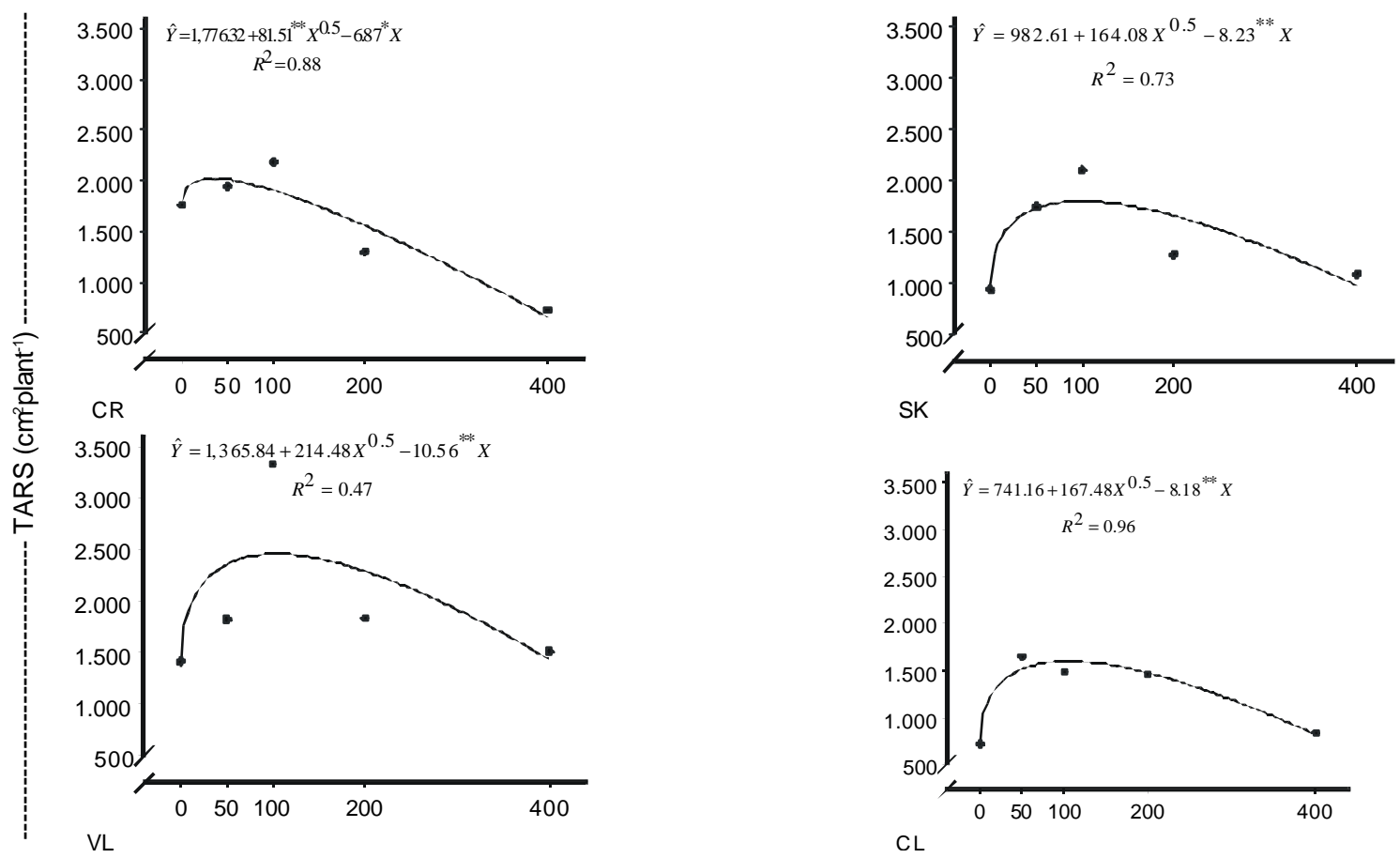

Al $\left(\mu \mathrm{mol} \mathrm{L} L^{-1}\right)$

$,{ }^{*},{ }^{* *}=$ Significant at 10,5 and $1 \%$, respectively, by Ftest

Figure 2 - Total length and area of the root system (TLRS and TARS) of 'Rangpur' lime (CR) and 'Volkamer' lemon (VL) and of 'Sunki' (SK) and Cleopatra' (CL) tangerines, as a function of the aluminium (Al) concentration in the nutrient solution. 
caused a decrease in leaf area, with lower production of photoassimilates utilized for plant growth. As a result, the rootstocks grew less, especially in the aerial part.

The root/shoot dry matter ratio (RSDMR) for all rootstocks reached a maximum value $\left(1.3 \mathrm{mg} \mathrm{mg}^{-1}\right)$ at estimated concentrations from 235 to $260 \mu \mathrm{mol} \mathrm{L}^{-1}$ aluminium (Figure 4). The greatest percentage increase

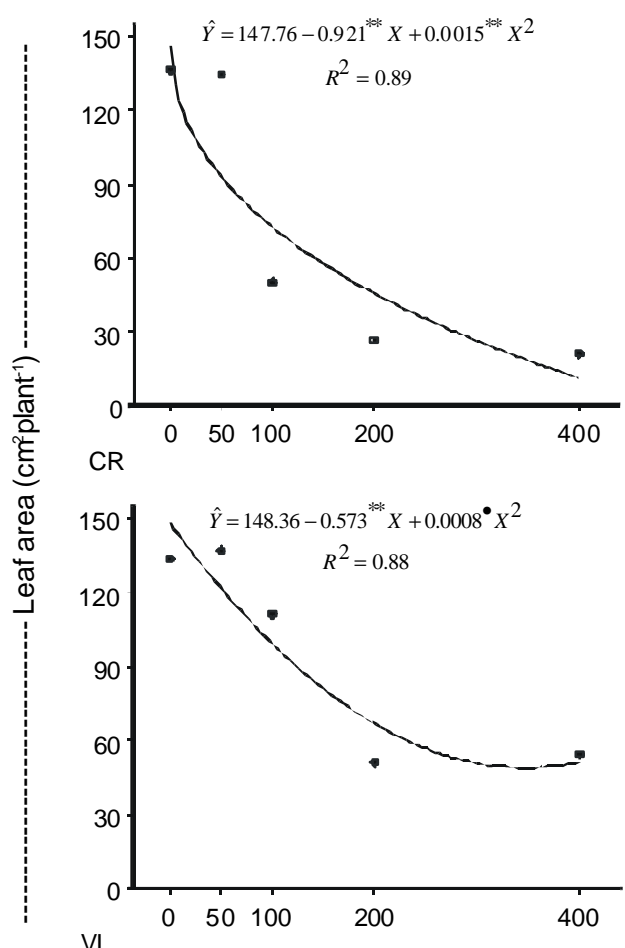

$\mathrm{VL}$

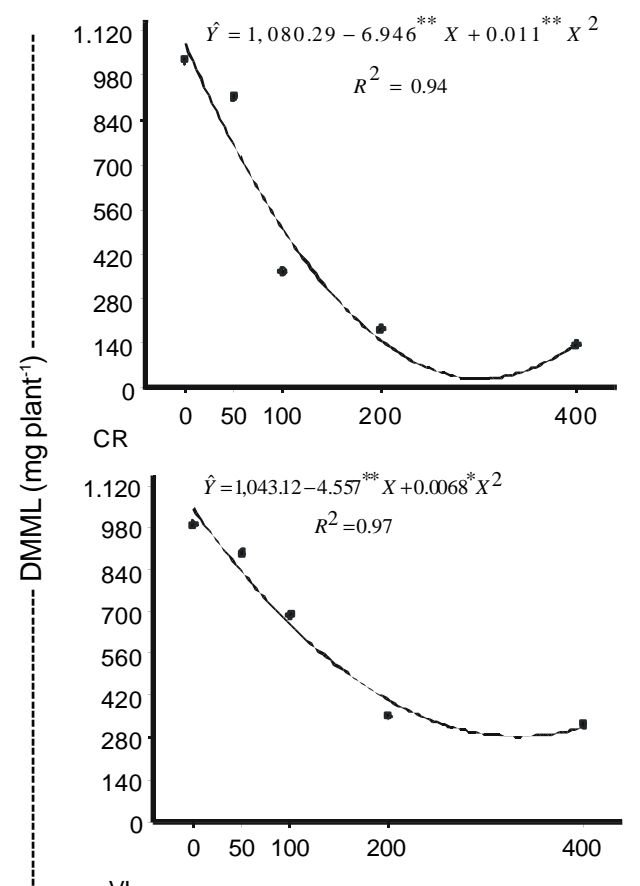

$\mathrm{VL}$ was verified for the 'Cleopatra' tangerine, and no differences were detected between the two lemons. When the two tangerine are compared to the two lemons, a higher increase was verified for the tangerines, and this can be credited to 'Cleopatra' (Tables 2 and 3 ).

In Prunus cerasus seedlings, there was a $188 \%$ increase in RSDMR when grown in a solution containing
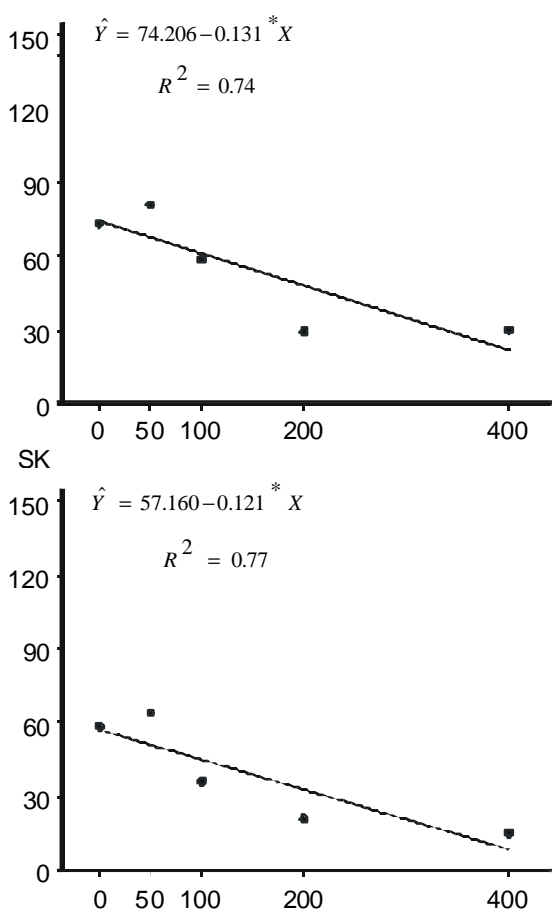

$\mathrm{Al}\left(\mu \mathrm{mol} \mathrm{L} \mathrm{L}^{-1}\right)$

$\mathrm{CL}$
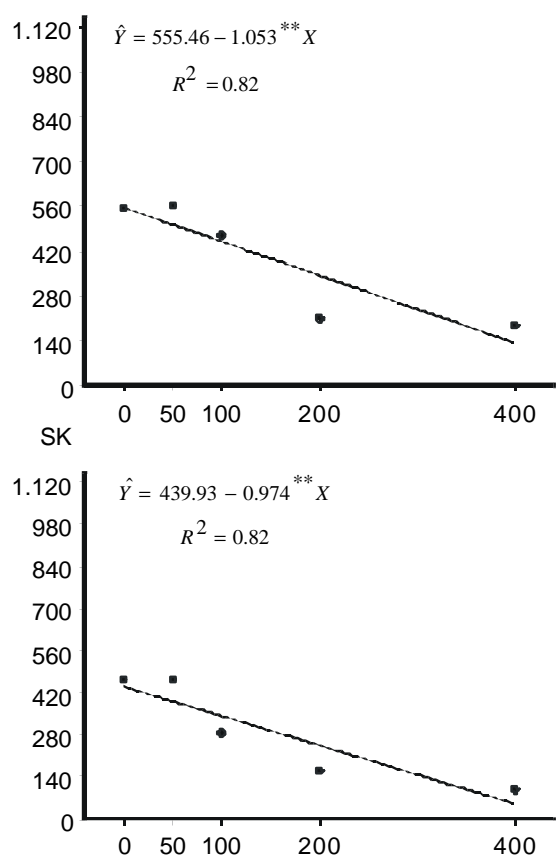

$\mathrm{CL}$

Al $\left(\mu \mathrm{mol} \mathrm{L} \mathrm{L}^{-1}\right)$

- ${ }^{*},{ }^{* *}=$ Significant at 10,5 and $1 \%$, respectively, by Ftest.

Figure 3 - Leaf area and leaf dry matter mass (DMML) of 'Rangpur' lime (CR) and 'Volkamer' lemons (VL) and of 'Sunki' (SK) and 'Cleopatra' (CL) tangerines, as a function of the aluminium (Al) concentration in the nutrient solution. 
2,222 $\mu \mathrm{mol} \mathrm{L}{ }^{-1} \mathrm{Al}$, decreasing at higher Al concentrations (Borkowska, 1991). Similar effects were verified for sorghum plants growing in a nutrient solution containing $100 \mu \mathrm{mol} \mathrm{L}{ }^{-1} \mathrm{Al}$ (Hodson \& Sangster, 1993). Pinto (1999) also verified that a $370 \mu \mathrm{mol} \mathrm{L^{-1 }} \mathrm{Al}$ concentration in the nutrient solution, can cause an increase in RSDMR for several citrus rootstocks. On the other hand, according to data presented by Santos et al. (1999), the presence of aluminium did not change this characteristic, both for the 'Rangpur' lime and the 'Swingle' citrumelo.

The increase in RSDMR verified in this experiment was due to the $\mathrm{Al}$ action, which made the leaf dry matter mass decrease (Figure 3 ) and caused an increase in root dry matter mass of three of the rootstocks under evaluation (Figure 1). This indicates that, under stress conditions, the plants allocated a greater amount of photoassimilates to the root system, in detriment to the aerial part. According to the quantitative model for the root/shoot ratio proposed by Thornley (1972), nutrient deficiencies, especially in $\mathrm{N}$ and $\mathrm{P}$, increase the allocation of photoassimilates to the root system. This increase depends on the nutrient translocation from the aerial part to the root system (Marschner et al., 1996).

In this experiment a decrease in $\mathrm{P}$ content in the aerial part of all rootstocks was verified (Pereira, 2001), and this could have been one of the reasons for the increase in RSDMR. Effects similar to those of $P$ deficiency on this ratio in soybean plants were verified by Freeden et al. (1989).

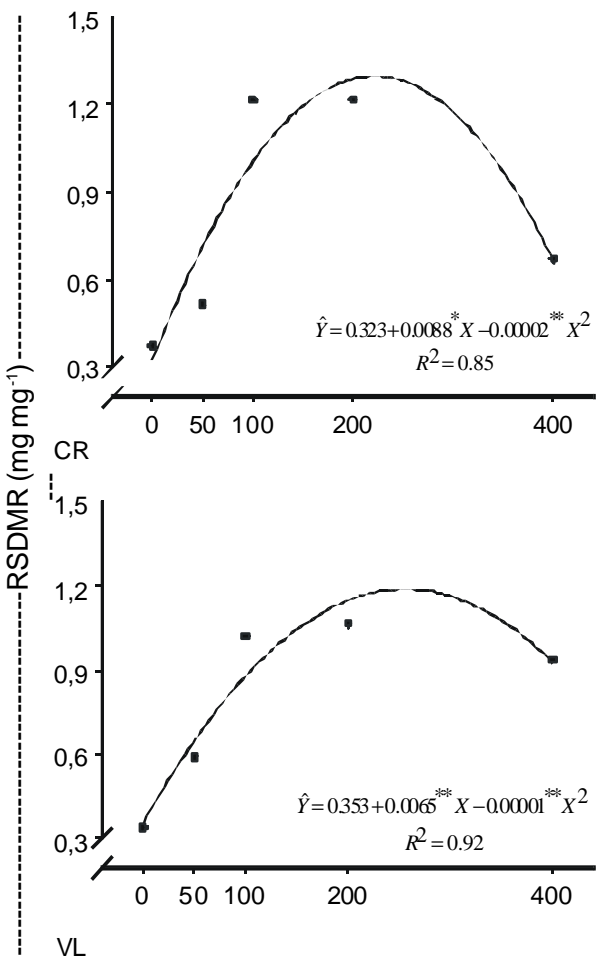

${ }^{*},{ }^{* *}=$ Significant at 5 and $1 \%$, respectively, by Ftest.

Figure 4 - Root/shoot dry matter ratio (RSDMR) for 'Rangpur' lime (CR) and 'Volkamer' lemon (VL) and for 'Sunki' (SK) and 'Cleopatra' (CL) tangerines, as a function of the aluminium $(\mathrm{Al})$ concentration in the nutrient solution.
In all rootstocks under evaluation, both the leaf area ratio (LAR) and the leaf weight ratio (LWR) initially decreased up to a concentration from 245 (CR)

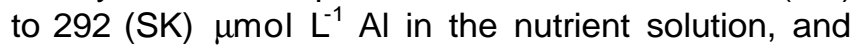
an increase in these characteristics occurred in the presence of higher $\mathrm{Al}$ concentrations (Figure 5). In relative values, the smallest decrease was verified for the 'Sunki' tangerine as compared to 'Cleopatra' (Tables 2 and 3). For the 'Volkamer' lemon there was a greater decrease in LWR as compared to 'Rangpur' lime.

The LAR is a morphological index of leaf area density, which allows a knowledge on the balance between the potentially photosynthesizing and the respiratory components of the plant (Hunt, 1990). The LWR measures the leafy character of plants based on dry matter, providing a knowledge on their potential in supporting the existing dry matter mass, as well as increasing it through photosynthesis (Beadle, 1993). Therefore, in this experiment, Al negatively affected the ability of all rootstocks to maintain and, or increase the existing dry matter, by rising the potential respiratory component of the plant.

Based on data presented by Pinto (1999), for 'Rangpur' lime seedlings exposed to $370 \mu \mathrm{mol} \mathrm{L}{ }^{-1} \mathrm{Al}$, a $27 \%$ decrease in LAR was verified, while for 'Cleopatra' tangerine seedlings the decrease was $15 \%$. On the other hand, based on data of Santos et al. (1999), no aluminium effect on LAR was verified for two evaluated
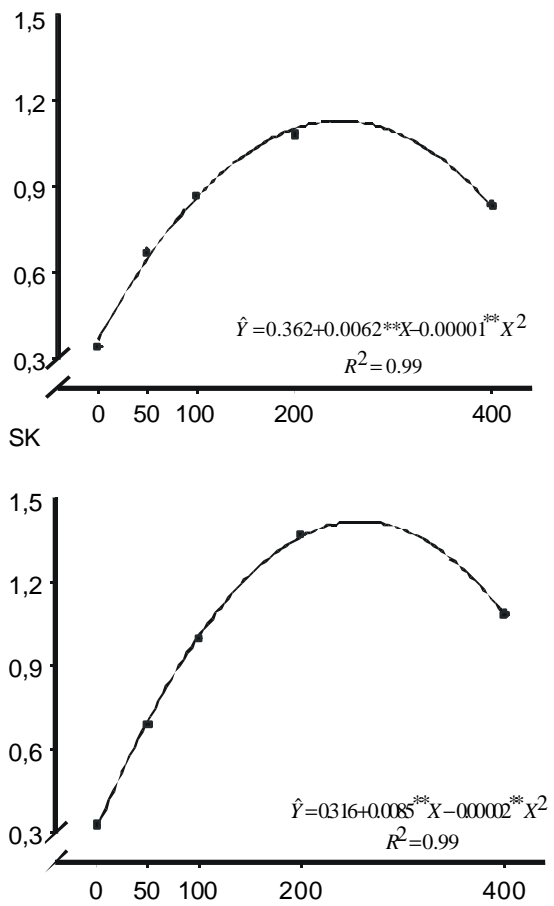

$\mathrm{CL}$
Al $\left(\mu \mathrm{mol} \mathrm{L} \mathrm{L}^{-1}\right)$ 
citrus rootstocks. According to data presented by Pinto (1999), 'Rangpur' lime and 'Cleopatra' tangerine seedlings exposed to $370 \mu \mathrm{mol} \mathrm{L}{ }^{-1} \mathrm{Al}$ presented a decrease of 17.4 and $18.2 \%$ in LWR, respectively. As

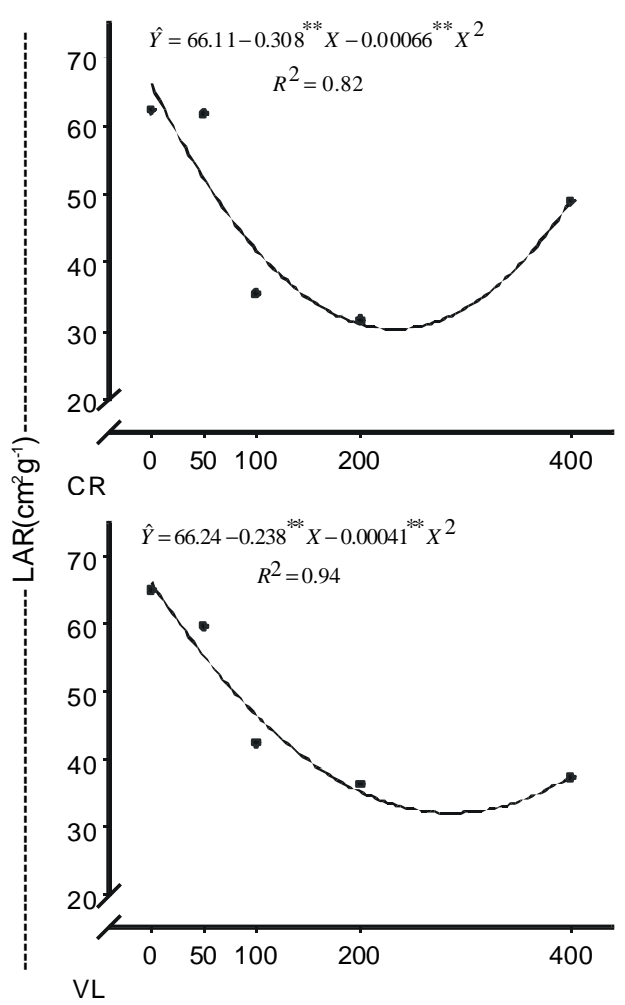

$\mathrm{Al}\left(\mu \mathrm{mol} \mathrm{L} \mathrm{L}^{-1}\right)$

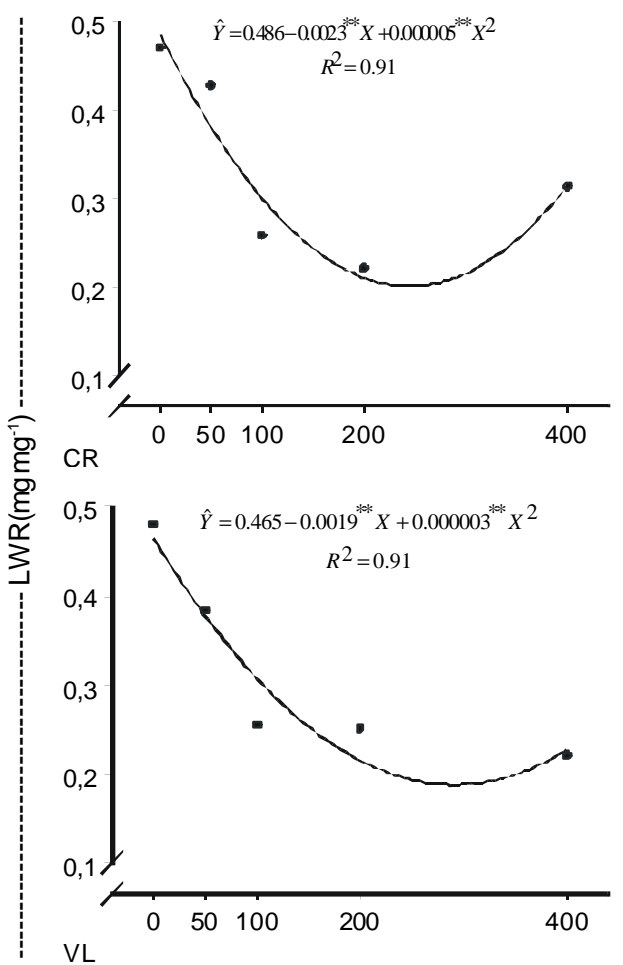

$\mathrm{Al}\left(\mu \mathrm{mol} \mathrm{L} \mathrm{L}^{-1}\right)$ the concentration of $\mathrm{Al}$ in the nutrient solution increased, there was a decrease in leaf area and dry matter mass for all rootstocks (Figure 3 ). This caused a decrease in LAR and LWR, since the total dry matter mass was less
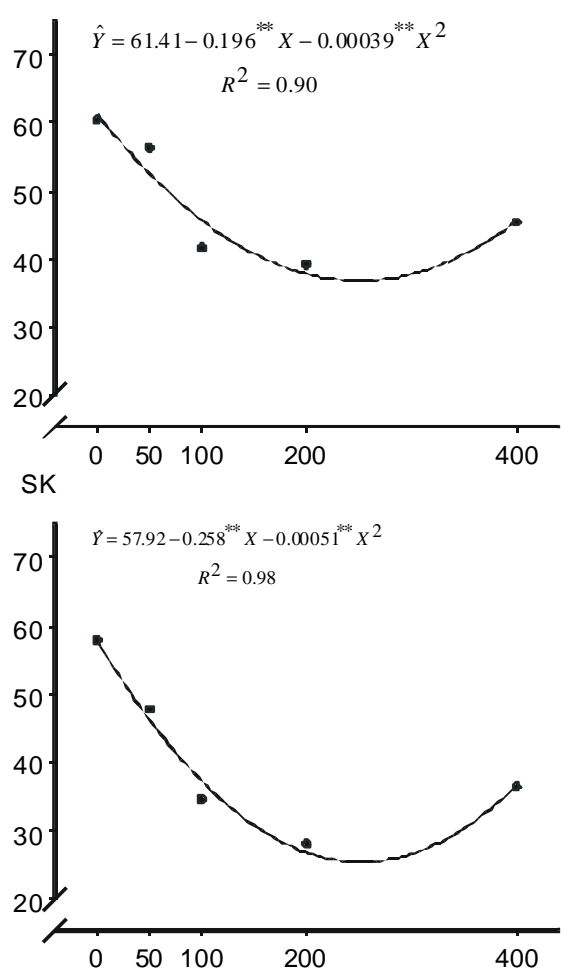

$\mathrm{CL}$
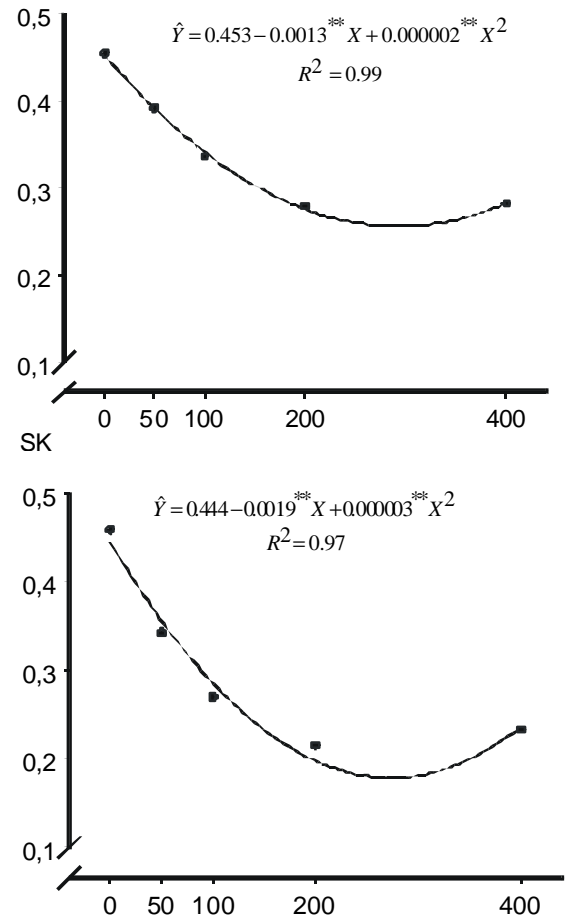

$\mathrm{CL}$

** $=$ Significant at $1 \%$ by $F$ test.

Figure 5 - Leaf area (LAR) and foliar mass (LWR) ratios for 'Rangpur' lime (CR) and 'Volkamer' lemon (VL) and for 'Sunki' (SK) and 'Cleopatra' (CL) tangerines, as a function of the aluminium (Al) concentration in the nutrient solution. 
affected, due to the increase in root dry matter mass in three (CR, SK and $C L$ ) of the evaluated rootstocks (Figure 1).

The principal components analysis, applied to the correlation matrix of relative values of growth characteristics, allowed two principal components to be identified, which represent $94 \%$ of the total variance of the original characteristics (Table 4). The first component represents the relative growth of the plant. The second principal component represents a contrast between the relative growth of the aerial part against the relative growth of the root system (Table 3). Therefore, if a given rootstock presents higher scores relative to another, it is because it presents higher relative values of root growth.

According to the classification based on scores of the first two principal components, it can be verified that, considering all growth-related characteristics, the 'Rangpur' lime was the most sensitive rootstock to aluminium (Figure 6). On the other hand, the 'Cleopatra' tangerine tree presented the greatest tolerance to

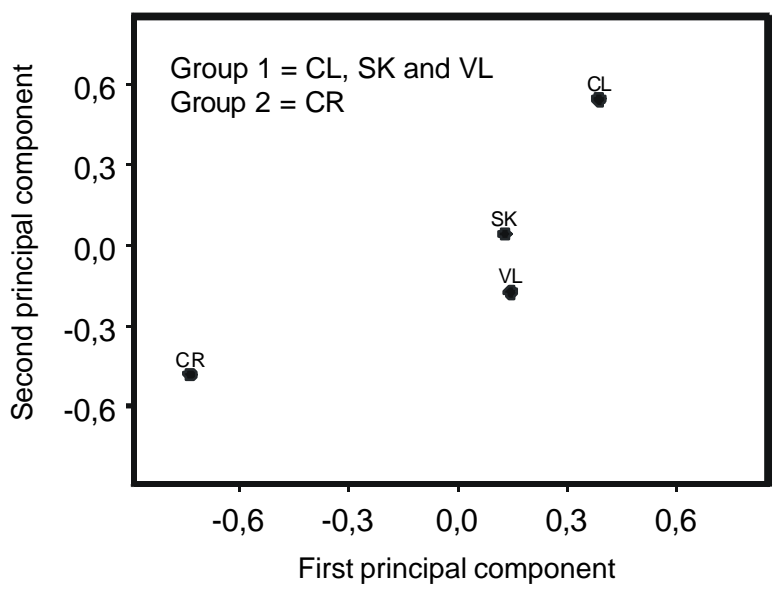

Figure 6 - Clustering of 'Rangpur' lime (CR) and 'Volkamer' lemon (VL) and of 'Sunki' (SK) and 'Cleopatra' (CL) tangerines, based on scores of the first and second principal components.

Table 4 - Eigenvectors in two principal components (PC1 and PC2) of values relative to the control, for dry matter mass in the root system (DMMRS); of the total area in the root system (TARS); of the total length of the root system (TLRS); of the leaf area (LA); of the dry matter mass in the leaves (DMML) and of the relative growth rate of the total fresh matter mass (RGR) of four citrus rootstocks submitted to aluminium stress

\begin{tabular}{lcc}
\hline Characteristic & CP1 & CP2 \\
\hline DMMRS & 0.38 & 0.37 \\
TARS & 0.36 & 0.44 \\
TLRS & 0.33 & 0.47 \\
LA & 0.38 & -0.40 \\
DMML & 0.37 & -0.41 \\
RGR & 0.44 & -0.04 \\
$\lambda$ & 4.65 & 1.92 \\
CVA (\%) & 66 & 94 \\
\hline
\end{tabular}

$\lambda=$ Eigenvalue of the correlation matrix. CVA $=$ cumulative variance. aluminium. These results coincide with those reported by Lin \& Myhre (1991) and Pinto (1999), who consider the 'Cleopatra' tangerine as one of the most tolerant citrus rootstocks to aluminium. The differences in behavior of the evaluated rootstocks facing aluminium stress could be due to the differential expression of one or more mechanisms of exclusion or internal tolerance to aluminium, described by Taylor $(1991 ; 1995)$ and Kochian (1995). The classification of the rootstocks 'Rangpur' lime and 'Cleopatra' relative to their tolerance to aluminium, based on growth characteristics, coincides with the classification based on the characteristics of gaseous exchanges and chlorophyll a (Pereira et al., 2000).

\section{REFERENCES}

ANDERSON, C.A. Fruit yields, tree size, and mineral nutrition relationships in 'Valencia' orange trees as affected by liming. Journal of Plant Nutrition, v.10, p.1907-1916, 1987

BEADLE, C.L. Growth analysis. In: HALL, D.O. Photosynthesis and production in a changing environment: a field and laboratory manual Londres: Chapman \& Hall, 1993. p.36-46.

BORKOWSKA, B. Experimental system for investigation of aluminium toxicity in fruit trees. In: WRIGHT, R.J. Plant-soil interactions at low pH Dordrecht: Kluwer Academic Publishers, 1991. p.999-1004

CANAL, I.N.; MIELNICZUK, J. Parâmetros de absorção de fósforo em milho, Zea mays L., afetados pela interação alumínio-cálcio. Ciência e Cultura, v.35, p.336-340, 1983

CLUNE, T.S.; COPELAND, L. Effects of aluminium on canola roots. Plant and Soil, v.216, p.27-33, 1999

CRUZ, C.D.; REGAZZI, A.J. Modelos biométricos aplicados no melhoramento genético. Viçosa: Imprensa Universitária UFV, 1994. 390p.

DEMATTE, J.L.; VITTI, G.C. Alguns aspectos relacionados ao manejo de solos para citros. In: SEMINÁRIO INTERNACIONAL DE CITROS, 2. Campinas, 1992. Anais. Campinas: Fundação Cargill, 1992. p.67-99.

FAO. FAO statistical database. http://apps.fao.org. (27/08/2000).

FIDALSKI, J.; PAVAN, M.A.; AULER, P.A.M.; JACOMINO, A.P. Produção de frutos de laranjeira Pêra e teores de nutrientes nas folhas e no solo, em Latossolo Vermelho-Escuro do noroeste do Paraná. Revista Brasileira de Ciência do Solo, v.23, p.273-279, 1999.

FNP Consultoria e Comércio. Laranja: área colhida. http://www.fnp.com.br. $(27 / 08 / 2000)$.

FOY, C.D. Effects of aluminium on plant growth. In: CARSON, E.W. The plan root and its environment. Charlottesville: Virginia University Press, 1974. p.601-642.

FOY, C.D. Plant adaptation to acid, aluminium-toxic soils. Communications in Soil and Plant Analysis, v.19, p.959-987, 1988

FOY, C.D.; CHANEY, R.L.; WHITE, M.C. The physiology of metal toxicity in plants. Annual Review of Plant Physiology, v.29, p.511-566, 1978.

FREEDEN A.L.; RAO, I.M.; TERRY, N. Influence of phosphorus nutrition on growth and carbon partitioning in Glicine max. Plant Physiology, v.89 p.225-230, 1989

GINTING, S.; JOHNSON, B.B.; WILKENS, S. Alleviation of aluminium phytotoxicity on soybean growth by organic anions in nutrient solutions. Australian Journal of Plant Physiology, v.25, p.901-908, 1998.

HODSON, M.J.; SANGSTER, A.G. The interaction between silicon and aluminium in Sorghum bicolor (L.) Moench: growth analysis and X-ray microanalysis. Annals of Botany, v.72, p.389-400, 1993.

HUNT, H. Basic growth analysis. Londres: Unwin Hyman, 1990. $112 \mathrm{p}$

JOHNSON, R.A.; WICHERN, D.W. Applied multivariate statistical analysis. Upper Saddle River: Prentice Hall, 1998. 816 p.

KINRAIDE, T. B.; PARKER, D. R. Cation amelioration of aluminium toxicity in wheat. Plant Physiology, v.83, p.546-551, 1987.

KOCHIAN, L.V.Cellular mechanism of aluminium toxicity and resistance in plants. Annual Review of Plant Physiology and Plant Molecular Biology, v.46, p.237-260, 1995.

KOZLOWSKI, T.T.; PALLARDY, S.G. Physiology of woody plants. San Diego: Academic Press, 1997. 411p.

LIN, Z.; MYHRE, D.L. Differential response of citrus rootstocks to aluminium levels in nutrient solutions: I. Plant growth. Journal of Plant Nutrition, v.14, p.1223-1238, 1991

LITTELL, R.C.; MILLIKEN, G.A.; STROUP, W.W.; WOLFINGER, R.D. SAS system for mixed models. Cary: SAS Institute, 1996. 633p. 
MAGALHÃES, A.F. de J. Tolerância de porta-enxertos de citrus ao alumínio. Revista Brasileira de Fruticultura, v.9, p.51-55,1987.

MARSCHNER, H.; KIRBBY, E.A.; CAKMAK, I. Effect of mineral nutritional status on shoot-root partitioning of photoassimilates and cycling of mineral nutrients. Journal of Experimental Botany, v.47, p.1255-1263, 1996.

MASON, M.. An investigation of reduction in wheat yields after use of a high level of ammonium sulphate for a number of years. Australian Journal of Experimental Agriculture and Animal Husbandry, v.20, p.210-219, 1980.

MASSOT, N.; LLUGANY, M.; POSCHENRIEDER, C.; BARCELO, J. Callose production as indicator of aluminium toxicity in bean cultivars. Journal of Plant Nutrition, v.22, p. 1-10, 1999.

NEOGY, M.; DATTA, J.K.; MUKHERJEE, S.; GORAI, A.K. Effect of aluminium on some physiological parameters and seed yield in mungbean (Vigna radiata L. Wilczek). Indian Journal of Plant Physiology, v.4, p.317-319, 1999.

NOGUEIRA, S. dos S.S.; NAGAI, V.; CARELLI, M.L.C.; FAHL, J. I. Comportamento de porta-enxertos de citros em presença do alumínio. Pesquisa Agropecuária Brasileira, v.24, p.711-716, 1989.

NUNES, M.A.; MATOS, C.M.; AZINHEIRA, H.G.; QUARTIN, V.L. Indirects effects of aluminium on photosynthesis and mineral concentration in triticales. In: MATHIS, P. Photosynthesis: from light to biosphere. Dordrecht: Kluwer Academic Publisher, 1995. v.4, p.713-716.

OLEKSYN, J.; KAROLEWSKI, P.; GIERTYCH, M.J.; WERNER, A.; TJOELKER, M.G.; REICH, P.B. Altered root growth and plant chemistry of Pinus sylvestris seedlings subjected to aluminum in nutrient solution. Trees: Structure and Function, v.10, p. 135-144, 1996.

PEREIRA W.E., SIQUEIRA, D.L., MARTÍNEZ, C.A., PUIATTI, M. Gas exchange and chlorophyll fluorescence in four citrus rootstocks under aluminium stress. Journal of Plant Physiology, v.157, p.513-520, 2000.

PEREIRA, W.E. Trocas gasosas, fluorescência da clorofila, crescimento e composição mineral de quatro porta-enxertos de citros submetidos a estresse por alumínio, em cultivo hidropônico. Viçosa, 2001. 123p. Tese (Doutorado) - Universidade Federal de Viçosa.
PINTO, I.S. Tolerância ao alumínio de cinco porta-enxertos de citros (Citrus spp.) cultivados em solução nutritiva. Cruz das Almas, 1999. 65p. Dissertação (Mestrado) - Universidade Federal da Bahia.

POMPEU JR., J. Porta-enxertos. In: RODRIGUEZ, O.; VIEGAS, F.P.; AMARO, A.A. Citricultura brasileira. 2 ed. Campinas: Fundação Cargil, , 1991. v. 1, p.264-280.

RENGEL, Z. Role of calcium in aluminium toxicity. New Phytologist, v.121, p.499-513, 1992.

SANTOS, C.H.; GRASSI FILHO, H.; RODRIGUES, J.D.; PINHO, S.Z. Níveis de alumínio e o desenvolvimento de porta-enxertos cítricos em cultivo hidropônico: I. Parâmetros biométricos. Scientia Agrícola, v.56, p.921932, 1999.

SAS INSTITUTE. SAS/STAT User's Guide: Version 8 Cary: SAS Institute Inc., 1999. $3.809 \mathrm{p}$

SIMON, L.; SMALLEY, T.J.; JONES, J. B.; LASSEIGNE, F.T. Aluminium toxicity in tomato. Part 1. Growth and mineral nutrition. Journal of Plant Nutrition, v.17, p.293-306, 1994.

TAYLOR, G.J. Current views of the aluminium stress response: the physiological basis of tolerance. Current Topics in Plant Biochemistry and Physiology, v.10, p.57-93, 1991.

TAYLOR, G.J. Overcoming barriers to understanding the cellular basis of aluminium resistance. Plant and Soil, v.171, p.89-103, 1995.

THORNLEY, J.H.M. A balanced quantitative model for root:shoot ratios in vegetative plants. Annals of Botany, v.36, p.431-441, 1972.

VASCONCELLOS, L.A.B.Z.; SIMAO, S.; MALAVOLTA, E.; CARMELLO, Q.A.C.; PREZOTO, M.E.M. Comportamento de porta-enxertos de citros (Citrus spp.) em três tipos de solos com diferentes níveis de alumínio e manganês. Laranja, v.10, p.281-295, 1989.

YAN, F.; SCHUBERT, S.; MENGEL, K. Effect of low root medium $\mathrm{pH}$ on net proton release, root respiration, and root growth of corn (Zea mays L.) and broad bean ( Vicia faba L.). Plant Physiology, v.99, p.415-421, 1992.

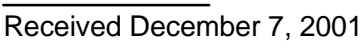

